\title{
Sources of Magnesium used in the Synthesis of Struvite from Wastewater: A Review
}

\author{
E. Mamakoa, E. Fosso-Kankeu*, V. Masindi and HWJP. Neomagus
}

\begin{abstract}
The use of magnesium sources such as magnesium hydroxide $\left(\mathrm{Mg}(\mathrm{OH})_{2}\right)$, magnesium oxide, pretreated magnesite $\left(\mathrm{MgCO}_{3}\right)$ and magnesium chloride, $\left(\mathrm{MgCl}_{2}\right)$ as precursor in the production of struvite has been explored by researchers. This study compares the different types of magnesium sources and their effectiveness in the production of struvite from wastewater effluents. A review of previous studies will be employed. The study will investigate the most effective magnesium salt in terms of environmental impacts, struvite quality, cost and availability. The study indicates that $\mathrm{MgCO}_{3}$ is the most cost effective, environmentally friendly and easily accessible source of magnesium for the synthesis of struvite from wastewater.
\end{abstract}

\section{Keywords - magnesium sources, struvite, wastewater}

\section{INTRODUCTION}

The precipitation of struvite from waste streams has gained attention of the scientific community due to its potential for phosphorus recovery for fertilization [1], as phosphate rock is expected to be depleted in the next 100 years [2]. The precipitation of struvite especially from wastewater supernatant is done to also manage the impacts of $\mathrm{P}$ and $\mathrm{N}$ in receiving natural waters [3], in a country already facing enormous challesges with regard to water pollution and physical scarcity [4-36]. The process has proven to be environmentally and economically viable method to reduce and recover phosphorus from wastewater [3] [37]. The addition of precursors in the form of magnesium sources has been recently investigated. The majority of the wastewater treatment plants use insoluble iron and aluminum salts to remove phosphate from sludge and then dispose the sludge at landfill sites, the water soluble magnesium sources like $\mathrm{MgCl}_{2}$ are also used to recover phosphate and form struvite [38]. Other sources of magnesium used for struvite

Manuscript received September 30th, 2019. This work was supported in part by the Council for Scientific and Industrial Research.

M.E Mamakoa is with Water Pollution and Monitoring Initiatives Group, School of Chemical and Minerals Engineering at North-west University, Potchefstroom, South Africa.

E Fosso-Kankeu is with the Water Pollution and Monitoring Initiatives Group, School of Chemical and Minerals Engineering at North-west University, Potchefstroom, South Africa

Vhahangwele Masindi is with Magalies water, Brits, North West Province, South Africa.

Hein Neomagus is with the School of Chemical and Minerals Engineering at North-west University, Potchefstroom, South Africa. formation include insoluble $\mathrm{MgCO}_{3}, \mathrm{Mg}(\mathrm{OH})_{2}$ and $\mathrm{MgO}$ [38]. The paper focuses on the comparison of the different magnesium sources in synthesizing struvite and reviewing their efficiencies in terms of environmental impact, cost, availability and struvite quality. According to [39] cumulative energy demand, global warming potential and acidification potential can be expected through the implementation of $\mathrm{P}$ recovery from wastewater [40-42]. This is mainly due to the high energy requirements needed to manufacture the chemicals used in the process. It is therefore, important to find more sustainable ways of producing struvite by focusing on readily available materials that are environmentally sustainable.

\section{METHOD}

\section{A. Research Activity}

A literature survey was done to gain an insight of the struvite formation process, identification and quality. The literature search using the Scopus database was done with struvite and wastewater in the search words from 1985 to 2019. The search resulted in 897 articles. In the results, papers published before 1994 accounted $0.4 \%$, and there was a considerable difference in publications per year and the number of publications per year varied with most articles published in 2018. Articles were then screened by selecting relevant papers based on the title and abstract of the articles. Articles dealing with struvite synthesis from wastewater were selected.

\section{B. Overview of publications per year}

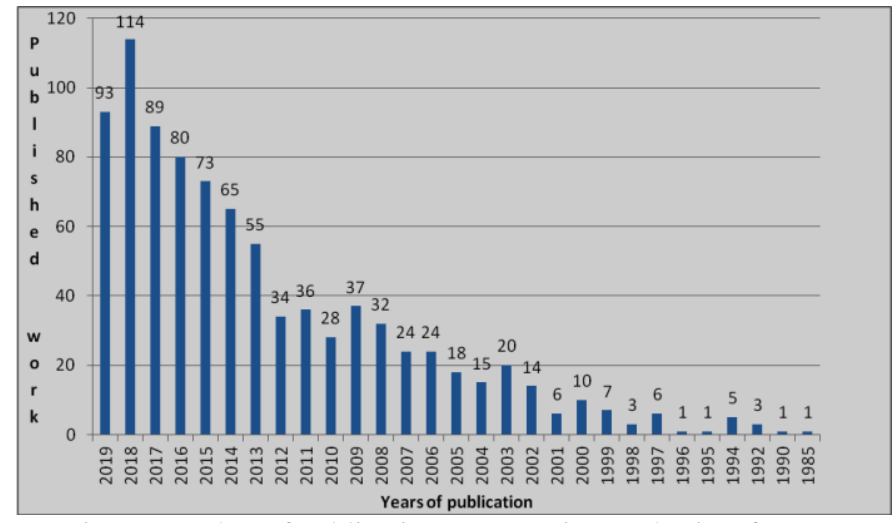

Fig. 1: Number of publications on struvite synthesis from wastewater per year

\section{RESULTS AND DISCUSSION}

The results reveal that the conventional method of 
synthesizing struvite is unsustainable due to the use of soluble magnesium salts like $\mathrm{MgCl}_{2}$ which is extracted from sea water or brine and require a lot of energy to produce. $\mathrm{MgO}$ also requires some processing; the energy requirements although minimal still contribute to the carbon footprint. $\mathrm{MgCO}_{3}$ (magnesite) is readily available and can be used raw for the synthesis of struvite. The process of producing different magnesium salts is seen in Figure 2

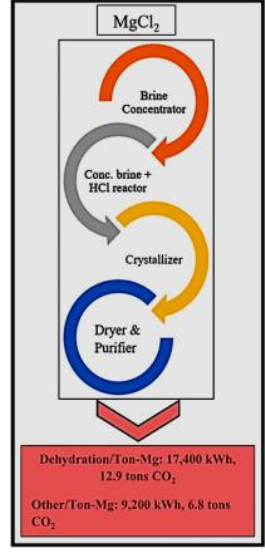

a)

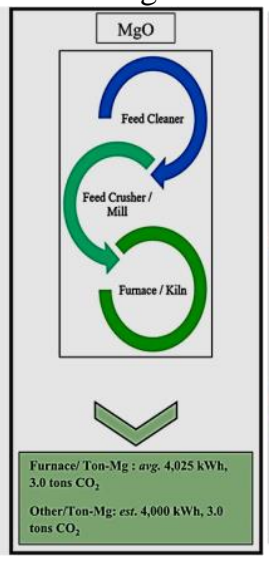

b)

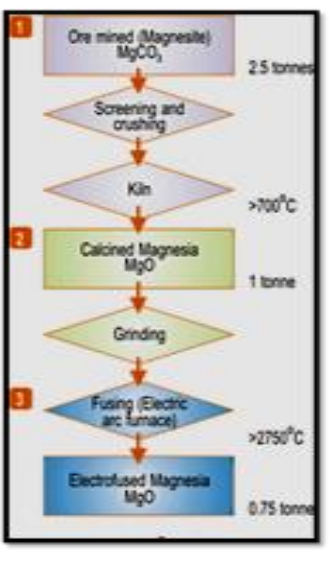

(c)
Fig. 2: The process of producing a. $\mathrm{MgCl}_{2}$, b. $\mathrm{MgO}$

$$
\text { c. } \mathrm{MgCO}_{3} \text { [43] }
$$

The sustainability of struvite synthesis is influenced by a number of factors like cost, availability and the environmental impact as seen in Table 1. The chemical cost varies based on wastewater composition and the chemicals being used. $\mathrm{MgCl}_{2}$ and $\mathrm{MgO}$ require energy to manufacture and process them as such they are expensive and they contribute to the carbon footprint. The latter have also contributed to the slow application of struvite synthesis by industry [2]. $\mathrm{MgCO}_{3}$ is cheaper and environmental friendly. South Africa is well-endowed with cryptocrystalline magnesite and as a developing country, it is important to find a low cost and easily accessible $\mathrm{Mg}$ source to make the process of struvite synthesis commercially attractive [37].

TABle I: FACtors Influencing The Use Of Magnesium Source [11]

\begin{tabular}{|c|c|c|c|}
\hline Magnesium source & Cost & Availability & $\begin{array}{l}\text { Environment } \\
\text { al impact }\end{array}$ \\
\hline $\mathrm{MgCl} 2$ & $\begin{array}{l}\text { USD } 0.04 / \mathrm{kg} \\
{[44]}\end{array}$ & $\begin{array}{l}\text { Easily } \\
\text { available }\end{array}$ & $\begin{array}{l}\text { Energy } \\
\text { intensive }\end{array}$ \\
\hline \multirow[b]{2}{*}{$\begin{array}{l}\mathrm{MgO} \\
\mathrm{MgCO}_{3}\end{array}$} & \multirow{2}{*}{$\begin{array}{l}\text { USD } 0.08 / \mathrm{kg} \\
{[44]} \\
\text { Naturally } \\
\text { occuring }\end{array}$} & \multirow{2}{*}{$\begin{array}{l}\text { Available } \\
\text { Easily } \\
\text { Available }\end{array}$} & $\begin{array}{l}\text { Requires } \\
\text { energy }\end{array}$ \\
\hline & & & $\begin{array}{l}\text { Carbon } \\
\text { footprint due } \\
\text { to } \\
\text { transportation }\end{array}$ \\
\hline
\end{tabular}

\section{A. Phosphate removal efficiency}

The results by [40] indicate that $\mathrm{MgO}$ gives higher phosphate removal efficiency than $\mathrm{MgCl}_{2}$ and [37] proved that $\mathrm{MgCO}_{3}$ is very efficient in phosphate removal from wastewater.

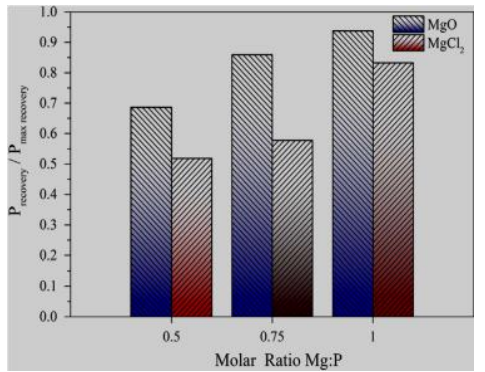

a)

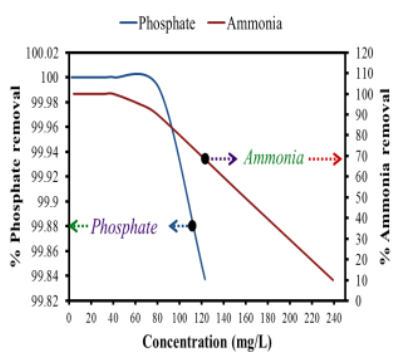

b)
Fig. 3: Phosphate removal efficiency a) $\mathrm{MgO}$ vs $\mathrm{MgCl}_{2}$ and b) $\mathrm{MgCO}_{3}$ [40] [37]

\section{B. Struvite quality}

Struvite crystallization includes nucleation and crystal growth (Morphology). There is limited research currently on struvite product quality. Morphology and crystal size are used to identify struvite [2]. The end use of struvite (product) depends on particle sizes and quality. The bigger particles are suitable for application as fertilizer because they are easy to transport, however, they lead to a slower fertilizer release rate, whereas the smaller particles reduce the loss of nutrients, thus, supporting the growth of plants [2]. The SEM results shown in Figure 4 indicates that $\mathrm{MgCl}_{2}$ as a precipitant creates rod- or coffin-like structures at lower ratios of $\mathrm{MgCl}_{2}: \mathrm{P}$ and highly dendritic crystalline structures at higher ratios. $\mathrm{MgO} / \mathrm{Mg}(\mathrm{OH})_{2}$ dissolution results in fast precipitation, instant nucleation, dendritic growth and small crystal sizes [40]. On the other hand, $\mathrm{MgCO}_{3}$ portrayed nanosheet-like structures with reduced size [37].
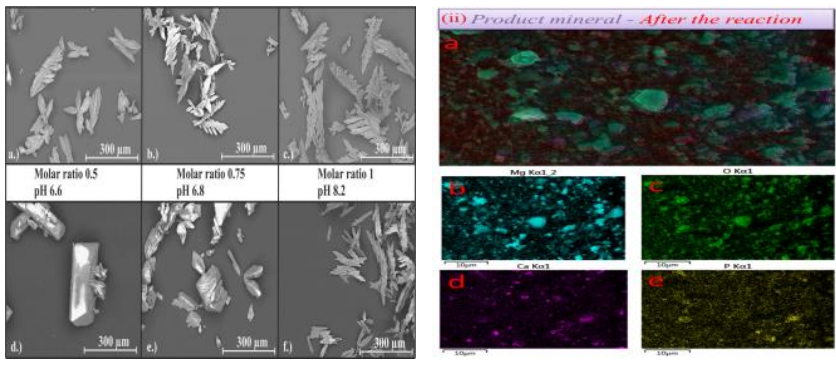

Fig. 4: $\mathrm{MgO}$ vs $\mathrm{MgCl}_{2}$ and $\mathrm{MgCO}_{3}$ product [40][37]

The sustainability analysis of struvite indicates that using $\mathrm{MgO}$ or various carbonates of magnesium to produce struvite significantly reduce energy requirements and the resulting carbon footprint by a factor of 3 compared to $\mathrm{MgCl}_{2}$, [43]. 
TABLE II: The Advantages AND DisAdVANTAGES OF MAGNESIUM SOURCES

\begin{tabular}{|c|c|c|c|}
\hline $\begin{array}{l}\text { Magnesium } \\
\text { source }\end{array}$ & Advantages & Disadvantages & $\begin{array}{l}\text { Reference } \\
\mathrm{s}\end{array}$ \\
\hline $\begin{array}{l}\text { Magnesium } \\
\text { Oxide }(\mathrm{MgO})\end{array}$ & $\mathrm{pH}$ increasing agent, & $\begin{array}{l}\text { Must be } \\
\text { prepared } 8-16 \\
\text { hours before } \\
\text { usage, Requires } \\
\text { energy to } \\
\text { process }\end{array}$ & $\begin{array}{l}\text { Shokouhi, } \\
2017 \text { [41] } \\
\text { Stolzenbur } \\
\text { g et al, } \\
2015 \text { [40] }\end{array}$ \\
\hline $\begin{array}{l}\text { Magnesium } \\
\text { hydroxide } \\
(\mathrm{Mg}(\mathrm{OH}) 2 \\
\text { Brucite }\end{array}$ & $\begin{array}{l}\text { pH increasing agents } \\
\text { Inexpensive, high } \\
\text { alkalinity, very low } \\
\text { concentrations of } \\
\text { heavy metals. Higher } \\
\text { solubility }\end{array}$ & $\begin{array}{l}\text { Inability to } \\
\text { attain an } \\
\text { equilibrium } \\
\text { solubility }\end{array}$ & $\begin{array}{l}\text { Shokouhi, } \\
2017 \text { [41] } \\
\text { Bishop, } \\
\text { 2006 [42] }\end{array}$ \\
\hline $\begin{array}{l}\text { Magnesium } \\
\text { Chloride } \\
\left(\mathrm{MgCl}_{2}\right)\end{array}$ & $\begin{array}{l}\text { Most popular, and } \\
\text { easily accessible } \mathrm{Mg} \\
\text { source }\end{array}$ & $\begin{array}{l}\text { Expensive to } \\
\text { synthesize, } \\
\text { High energy } \\
\text { requirements } \\
\text { High carbon } \\
\text { footprint }\end{array}$ & $\begin{array}{l}\text { Shokouhi,2 } \\
017 \text { [41] } \\
\text { Kiani et al, } \\
2019 \text { [43] }\end{array}$ \\
\hline $\begin{array}{l}\text { Cryptocristalline } \\
\text { Magnesite } \\
\left(\mathrm{MgCO}_{3}\right)\end{array}$ & $\begin{array}{l}\text { Low cost, Easily } \\
\text { accessible } \\
\text { Characterised of } \mathrm{Mg} \text {, } \\
\mathrm{Ca}, \mathrm{Fe} \text { and } \mathrm{Si} \\
\text { sandwiched together } \\
\text { gives it up hand due to } \\
\text { hybrid properties, } 60 \\
\text { megatons deposits in } \\
\text { SA Reduced } \\
\text { environmental impact }\end{array}$ & $\begin{array}{l}\text { A lot of sludge } \\
\text { produced }\end{array}$ & $\begin{array}{l}\text { Mavhungu } \\
\text { et al, 2019 } \\
{[37],} \\
\text { Masindi, et } \\
1,2015 \\
{[45], \text { Hoon, }} \\
2013 \text { [46] }\end{array}$ \\
\hline
\end{tabular}

\section{CONCLUSION}

Economical analysis of struvite crystallization renders it not feasible. However, looking at the environmental benefits of reducing/preventing eutrophication and increasing the use of available renewable resources, phosphorus recovery maybe an economically feasible process. The use of naturally occurring magnesium sources has proven to be the most sustainable method of struvite synthesis with minimal impacts to the environment and the materials are always available. It is therefore, the conclusion that $\mathrm{MgCO}_{3}$ is a better source of magnesium for struvite formation from wastewater.

\section{ACKNOWLEDGMENT}

The authors acknowledge the support from the North-West University, and the Council for Scientific and Industrial Research (CSIR) for awarding an MSc bursary to Ms Mamakoa.

\section{REFERENCES}

[1] Yan, H., Shih, K., 2016. Effects of calcium and ferric ions on struvite precipitation: A new assessment based on quantitative X-ray diffraction analysis. Water Research 95, 310-318. https://doi.org/10.1016/j.watres.2016.03.032

[2] Bing Li a,b, Irina Boiarkinaa,Wei Yu a, $\square$, Hai Ming Huang c, TajammalMunir a, GuangQianWang b, Brent R. Young, 2018, Phosphorous recovery through struvite crystallization: Challenges for future design, Science of the Total Environment 648 (2019) 1244-1256 https://doi.org/10.1016/j.scitotenv.2018.07.166

[3] Yetilmezsoy, K., Ilhan, F., Kocak, E., Akbin, H.M., 2017. Feasibility of struvite recovery process for fertilizer industry: A study of financial and economic analysis. J. Clean. Prod.152, 88-102.

ttps://doi.org/10.1016/j.jclepro.2017.03.106
[4] Elvis Fosso-Kankeu. 2019. Nano and Bio-based Technologies for wastewater treatment: Prediction and Control Tools for the dispersion of Pollutants in the Environment. Wiley Scrivener. ISBN: 978-1-119-57709-6. Pp 301-336.

[5] Elvis Fosso-Kankeu. 2019. New Horizons in Wastewaters Management: Emerging Monitoring and Remediation Strategies. Nova Science Publishers. ISBN: 978-1-53615-659-1.

[6] J.G. Redelinghuys, E. Fosso-Kankeu, G. Gericke, F. Waanders. 2019. Coal Power Plant Wastewater Treatment by Thermal and Membrane Technologies. In Nano and Bio-based Technologies for wastewater treatment: Prediction and Control Tools for the dispersion of Pollutants in the Environment. Editor: Elvis Fosso-Kankeu. Wiley Scrivener. ISBN: 978-1-119-57709-6. Pp 149-168. https://doi.org/10.1002/9781119577119.ch5

[7] N. Mukwevho, E. Fosso-Kankeu, F. Waanders. 2019. PAHs Released from Coal Tars and Potential Removal Using Nanocatalysts. In Nano and Bio-based Technologies for wastewater treatment: Prediction and Control Tools for the dispersion of Pollutants in the Environment. Editor: Elvis Fosso-Kankeu. Wiley Scrivener. ISBN: 978-1-119-57709-6. Pp 169-203. https://doi.org/10.1002/9781119577119.ch6

[8] Enoch A. Akinpelu, Elvis Fosso-Kankeu, Seteno K.O. Ntwampe, Frans Waander. 2019. Stoichiometric and thermodynamic analysis: implications in bioremediation. In New Horizons in Wastewaters Management: Emerging Monitoring and Remediation Strategies. Editor: Elvis Fosso-Kankeu. Nova Science Publishers. ISBN: 978-1-53615-659-1.

[9] Corli de Klerk,Elvis Fosso-Kankeu and Frans Waanders. 2019. Nanoparticle-biopolymer antimicrobial compounds as sustainable option for wastewater treatment. In New Horizons in Wastewaters Management: Emerging Monitoring and Remediation Strategies. Editor: Elvis Fosso-Kankeu. Nova Science Publishers. ISBN: 978-1-53615-659-1.

[10] Nthambeleni Mukwevho, Elvis Fosso-Kankeu, Frans Waanders, Neeraj Kumar, Suprakas Sinha Ray, Xavier Yangkou Mbianda. 2019. Evaluation of the photocatalytic activity of $\mathrm{Gd}_{2} \mathrm{O}_{2} \mathrm{CO}_{3} \cdot \mathrm{ZnO} \cdot \mathrm{CuO}$ nanocomposite used for the degradation of phenanthrene. Springer Nature Applied Sciences. https://doi.org/10.1007/s42452-018-0012-0. 1-10.

[11] Fosso-Kankeu E., Potgieter J. and Waanders F.B. 2019. Removal of malachite green and toluidine blue dyes from aqueous solution using a clay-biochar composite of bentonite and sweet sorghum bagasse. International Journal of Applied Engineering Research. 14(6): 1324-1333.

[12] Johannes Cornelius van der Linde, Elvis Fosso-Kankeu, Gerhard Gericke, Frans Waanders, Louise Dreyer, Nico Lemmer. 2019. Flocculant types and operating conditions influencing particles settling rates in feed water used at a coal power plant. Desalination and Water Treatment. 150: 293-300. https://doi.org/10.5004/dwt.2019.23735

[13] IG Erdogan, L Mekuto, SKO Ntwampe, E Fosso-Kankeu, FB Waanders. 2019. Metagenomic profiling dataset of bacterial communities of a drinking water supply system (DWSS) in the arid Namaqualand region, South Africa: Source (lower Orange River) to point-of-use (O'kiep). Journal of Data in Brief. 25: 104135-104140. https://doi.org/10.1016/j.dib.2019.104135

[14] N Kumar, E Fosso-Kankeu, SS Ray. 2019. Achieving controllable MoS2 nanostructures with increased interlayer spacing for efficient removal of $\mathrm{Pb}$ (II) from aquatic systems. ACS Applied Materials and Interfaces. 11: 19141-19155. https://doi.org/10.1021/acsami.9b03853

[15] N Mukwevho, N Kumar, E Fosso-Kankeu, F Waanders, J Bunt, SS Ray. 2019. Visible light-excitable $\mathrm{ZnO} / 2 \mathrm{D}$ graphitic-C3N4 heterostructure for the photodegradation of naphthalene. Desalination and Water Treatment. 163: $286-296$ https://doi.org/10.5004/dwt.2019.24422

[16] E Fosso-Kankeu, R Weideman, D Moyakhe, FB Waanders, M Le Roux, QP Campbell. 2019. Hydrothermal preparation of biochar from spent coffee grounds, and its application for the removal of cadmium from coal tailings leachate. The Journal of the Southern African Institute of Mining and Metallurgy. 119: 607-612.

https://doi.org/10.17159/2411-9717/449/2019 
[17] R Gusain, N Kumar, E Fosso-Kankeu, SS Ray. 2019. Efficient removal of $\mathrm{Pb}$ (II) and $\mathrm{Cd}$ (II) from industrial mine water by a hierarchical MoS2/SH-MWCNT nanocomposite. ACS Omega. 4: 13922-13935. https://doi.org/10.1021/acsomega.9b01603

[18] Nthambeleni Mukwevho, Rashi Gusain, Elvis Fosso-Kankeu, Neeraj Kumar, Frans Waanders, Suprakas Sinha Ray. 2019. Removal of naphthalene from simulated wastewater through adsorption-photodegradation by $\mathrm{ZnO} / \mathrm{Ag} / \mathrm{GO}$ nanocomposite. Journal of Industrial and Engineering Chemistry. ttps://doi.org/10.1016/j.jiec.2019.09.030

[19] Erdogan IC, Fosso-Kankeu E, Ntwampe SKO, Waanders FB, Hoth N, Rand A, Farrar TJ. 2019. Households water quality in O'kiep - South Africa and community perception of related health risks. 167(2019): 145-155. https://doi.org/10.5004/dwt.2019.24576

[20] IG Erdogan, E Fosso-Kankeu, SKO Ntwampe, FB Waanders, N Hoth and A Rand. 2019. Acid rock drainage prediction of metalliferous soils from O'kiep, Namaqualand, South Africa: A humidity cell test assessment. IMWA 2019 Conference "Mine Water - Technological and Ecological Challenges". 15-19 July 2019, Perm, Russia. Elena Khayrulina and Christian Wolkersdorfer. ISBN: 978-5-91252-145-4. Pp 613-618.

[21] E Fosso-Kankeu, N Kumar, S Pandey, SS Ray. 2019. Synthesis of MoS2-Based nanohybrid for effective removal of mercury from aqueous solution. IMWA 2019 Conference "Mine Water - Technological and Ecological Challenges". 15-19 July 2019, Perm, Russia. Elena Khayrulina and Christian Wolkersdorfer. ISBN: 978-5-91252-145-4. Pp 175-178.

[22] N Mukwevho, E Fosso-Kankeu, N Kumar, R Gusain, S Ray, F Waanders. 2019. PAHs in coal tar as water contaminants and their removal by photocatalytic degradation. IMWA 2019 Conference "Mine Water Technological and Ecological Challenges". 15-19 July 2019, Perm, Russia. Elena Khayrulina and Christian Wolkersdorfer. ISBN: 978-5-91252-145-4. Pp 179-183.

[23] E Fosso-Kankeu, R Weideman, D Moyakhe, F Waanders, Q Campbell. 2019. Thermodynamic study of the adsorption performance of spent coffee beans for the removal of cadmium from coal tailing leachates. IMWA 2019 Conference "Mine Water - Technological and Ecological Challenges". 15-19 July 2019, Perm, Russia. Elena Khayrulina and Christian Wolkersdorfer. ISBN: 978-5-91252-145-4. Pp 184-188.

[24] E. Fosso-Kankeu, A.F. Mulaba-Bafubiandi, B.B. Mamba and T.G. Barnard, Prediction of metal-adsorption behaviour in the remediation of water contamination using indigenous microorganisms. Journal of Environmental Management. Vol. 92, no. 10, pp. 2786-2793, 2011. https://doi.org/10.1016/j.jenvman.2011.06.025

[25] H. Mittal, E. Fosso-Kankeu, Shivani B. Mishra, Ajay K. Mishra, Biosorption potential of Gum ghatti-g-poly (acrylic acid) and susceptibility to biodegradation by B. subtilis. International Journal of Biological Macromolecules. Vol. 62, pp. 370-378, 2013. https://doi.org/10.1016/j.ijbiomac.2013.09.023

[26] E. Fosso-Kankeu, H. Mittal, S.B. Mishra, A.K. Mishra, Gum ghatti and acrylic acid based biodegradable hydrogels for the effective adsorption of cationic dyes. Journal of Industrial and Engineering Chemistry. Vol. 22, pp. 171-178, 2015. https://doi.org/10.1016/j.jiec.2014.07.007

[27] E. Fosso-Kankeu, F. Waanders, E. Maloy, Copolymerization of ethyl acrylate onto guar gum for the adsorption of $\mathrm{Mg}$ (II) and $\mathrm{Ca}$ (II) ions. Desalination and Water Treatment. doi: 10.1080/19443994.2016.1165147: pp. 1-10, 2016.

[28] E. Fosso-Kankeu, F. Waanders, C.L. Fourie, Adsorption of Congo Red by surfactant-impregnated bentonite clay. Desalination and Water Treatment. doi: 10.1080/19443994.2016.1177599: pp. 1-9, 2016.

[29] E. Fosso-Kankeu, A. Manyatshe, F. Waanders, Mobility potential of metals in acid mine drainage occurring in the Highveld area of Mpumalanga Province in South Africa: Implication of sediments and efflorescent crusts. International Biodeterioration and Biodegradation. Vol. 119, pp. 661-670, 2017. https://doi.org/10.1016/j.ibiod.2016.09.018

[30] E. Fosso-Kankeu, H. Mittal, F. Waanders, S.S. Ray, Thermodynamic properties and adsorption behaviour of hydrogel nanocomposites for cadmium removal from mine effluents. Journal of Industrial and Engineering Chemistry. Vol. 48, pp. 151-161, 2017. https://doi.org/10.1016/j.jiec.2016.12.033
[31] E. Fosso-Kankeu, F.B. Waanders, F.W. Steyn, Removal of Cr(VI) and $\mathrm{Zn}$ (II) from an aqueous solution using an organic-inorganic composite of bentonite-biochar-hematite. Desalination and Water Treatment. Vol. 59, pp. 144-153, 2017. https://doi.org/10.5004/dwt.2017.0059

[32] A. Manyatshe, E. Fosso-Kankeu, D. van der Berg, N. Lemmer, F. Waanders, H. Tutu, Dispersion of inorganic contaminants in surface water in the vicinity of Potchefstroom. Physics and Chemistry of the Earth. Vol. 100, pp. 86-93, 2017. https://doi.org/10.1016/j.pce.2017.04.008

[33] C. de Klerk, E. Fosso-Kankeu, F.B. Waanders, Evaluation of the antibacterial activity of metal impregnated multi-walled carbon nanotubes: impact of domestic wastewater as supporting medium. Desalination and Water Treatment.Vol. 99, pp. 272-281, 2017. https://doi.org/10.5004/dwt.2017.21735

[34] A. Manyatshe, E. Fosso-Kankeu, D. van der Berg, N. Lemmer, F. Waanders, H. Tutu, Metal speciation in the rivers around Potchefstroom based on seasonality. Water Environment Research. Vol. 90, no. 1, pp. 84-95, 2018. https://doi.org/10.2175/106143017X15054988926587

[35] L.P. Simelane, E. Fosso-Kankeu, P. Njobeh, S. Pandey, Response of bacterial biosorbents to chemical treatment as influenced by cell membrane structure and impact on the adsorption behaviour of dyes. Current Science. Vol. 114, no. 4, pp. 826-834, 2018 https://doi.org/10.18520/cs/v114/i04/826-834

[36] E. Fosso-Kankeu, 2018. Synthesized af-PFCl and GG-g-P(AN)/TEOS hydrogel composite used in hybridized technique applied for AMD treatment. Journal of Physics and Chemistry of the Earth. 2018. https://doi.org/10.1016/j.pce.2018.02.015

[37] Mavhungu A., Mbaya K., Masindi V, Muedi K.L and Mpenyana-Monyatsi, L, 2019. Facile Synthesis of Struvite from Municipal WastewaterUsingPre-Treated Magnesite, the 10th International Conference on Advances in Chemical, Agricultural, Biological \& Environmental Sciences (ACABES-18) Nov. 19-20 2018 Cape Town (South Africa)

[38] Kirinovic, E, Leichtfuss, AR., Navizaga, C, Zhang, H, Schuttlefield Christus, J.D., and Baltrusaitis, J, ACS Sustainable Chemistry \& Engineering 20175 (2),1567-1577,DOI:10.1021/acssuschemeng.6b023 27

[39] Amann A. Zoboli,O. Krampe J. Rechberger H. Zessner M. Eglea L., 2018, Environmental impacts of phosphorus recovery from municipal wastewater, Resources, Conservation \& Recycling 130 (2018) 127-139 https://doi.org/10.1016/j.resconrec.2017.11.002

[40] Stolzenburg P, Capdevielle A, Teychené S, and Biscans B. Struvite precipitation with $\mathrm{MgO}$ as a precursor: Application to wastewater treatment, Journal of chemical engineering, vol 133, pp 9-15 https://doi.org/10.1016/j.ces.2015.03.008

[41] Shokouhi, A., 2017. Phosphorus Removal from Wastewater through Struvite Precipitation, Norwegian University of Life Sciences, Faculty of Environmental Sciences and Natural Resource Management, Masters Thesis

[42] P, L., Bishop , 2006. Control of Struvite Deposition in Wastewater Treatment Plants, $11^{\text {th }}$ Annual Central States Water Environment Association Education Conference

[43] Kiani D, Sheng Y, Lu B, Barauskas D, Honer K, Jiang, Z and Baltrusaitis J, Transient Struvite Formation during Stoichiometric (1:1) NH + and PO43- Adsorption/Reaction on Magnesium Oxide (MgO) Particles, ACS Sustainable Chem. Eng, 2019, 7, 1545-1556 https://doi.org/10.1021/acssuschemeng.8b05318

[44] Huang H, Xiao D, Zhang Q and Ding L., 2014. Removal of ammonia from landfill leachate by struvite precipitation with the use of low-cost phosphate and magnesium sources, Journal of Environmental Management, vol 145, pp 191-198. https://doi.org/10.1016/j.jenvman.2014.06.021

[45] Masindi, W. Gitari, K. Pindihama, Synthesis of nanocomposite of cryptocrystalline magnesite-bentonite clay and its application for phosphate removal from municipal effluents, Environ. Technol., (2015) $1-27$. https://doi.org/10.1080/19443994.2015.1110720

[46] Hoon, H, 2013. The removal methods of phosphorus/phosphate and nitrogen /nitrate from water and wastewater, Thesis for the degree in Chemistry and Biology, Tunku Abdul Rahman University College. 


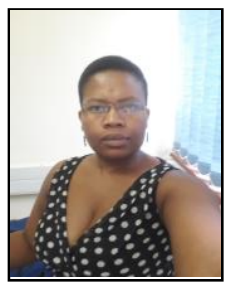

Ednah Mamakoa was born in Mokopane Limpopo Province South Africa. She holds a BSc Community Water Services and Sanitation from University of Limpopo Turfloop South Africa, A BSc Hons Environmental Management at University of South Africa Pretoria, GDE in Civil and Environmental Engineering at University of Witwatersrand Johannesburg and currently registered for MSc in Chemical Engineering at Northwest University

Potchefstroom

She has over eight years post graduate experience at Council for Scientific and Industrial Research working as a RESEARCHER in the field of environmental management focusing mainly on water and wastewater in the mining, water services and sanitation sectors. She has been directly involved in integrated water resources management, water quality management, wastewater treatment, groundwater development, poverty alleviation and stakeholder participation, and implementation and evaluation of water and sanitation projects. In addition, she also has extensive experience in policy formulation and analysis at the national, regional and international levels having worked for the research institution and implemented policy review and formulation projects. She has disseminated the research findings through publications, including journal, as well as the preparation and presentation of papers in local conferences.

Ms Mamakoa has been awarded MSc Bursary by the CSIR. She is a member of Young Water Professionals and South African Council for Natural Scientific Professionals. 